\title{
IMPLEMENTASI PROGRAM KEPROFESIAN BERKELANJUTAN MELALUI MUSYAWARAH GURU MATA PELAJARAN FISIKA DI SMA NEGERI DAN SWASTA KABUPATEN INDRAGIRI HILIR PROVINSI RIAU
}

\author{
Agus Purnomo ${ }^{1)}$ \\ Sumardi ${ }^{2)}$ \\ Zulkarnain ${ }^{3)}$ \\ 1) Post Graduate Student of Riau University \\ 2) Lecturer of Education Management Study Programme PPs University of Riau \\ 3) Lecturer of Education Management Study Programme PPs University of Riau
}

\begin{abstract}
This research aims, (1) To find out the consistency of Physics MGMP management standards in SMA Negeri dan swasta of Indragiri Hilir Regency, Riau Province, (2) To know the utilization of resources in SMA Negeri dan swasta of Indragiri Hilir Regency, Riau Province, (3) To find out activities and communication in SMA Negeri dan swasta of Indragiri Hilir Regency, Riau Province, (4) To find out the patterns of implementing Physics MGMP in SMA Negeri dan swasta of Indragiri Hilir Regency, Riau Province, (4) To find out Government and School Principal support for Physics MGMP in SMA Negeri dan swasta of Indragiri Hilir Regency, Riau Province, (5) To find out the response of the Physics MGMP implementor in SMA Negeri dan swasta of Indragiri Hilir Regency, Riau Province. The research respondents were administrators and several members of the High School Physics MGMP in Indragiri Hilir Regency. The results obtained from this study are (1) Consistency of MGMP Physics standards in SMA Negeri dan swasta of Indragiri Hilir Regency, Riau Province MGMP Physics Communities in SMA Negeri dan swasta of Indragiri Hilir Regency, Riau Province. District Private High Schools is good because it is consistent with MGMP technical guidelines and operational standards. However, there are operational standards that have not been well guided, (2) Utilization of resources in Physics MGMP in SMA Negeri dan swasta of Indragiri Hilir Regency, Riau Province, (3) Activities and Communication in Physics MGMP in SMA Negeri dan swasta of Indragiri Hilir Regency, Riau Province level have been carried out well, namely in the delivery of information both messages, ideas, ideas carried out verbally or by means of communication based tools, (4) Patterns of implementation of activities Physics MGMP in SMA Negeri dan swasta of Indragiri Hilir Regency, Riau Province is already good with the implementation pattern is routinely carried out every month. , (5) Government and School Support for State and Private High School Physics MGMP of Indragiri Hilir Regency is already good because in the implementation of Physics MGMP always receives support from Schools in the form of MGMP Physics activity fund assistance sourced from school operational assistance funds, (6) Implementor response to the PKB program through the Physics MGMP in SMA Negeri dan swasta of Indragiri Hilir Regency, Riau Province has not included material for making scientific articles, textbooks, learning modules and innovative works.
\end{abstract}

Keywords: Sustainable Professional Program; Teacher's Meeting of Physics Subjects 


\begin{abstract}
ABSTRAK
Peneitian ini bertujuan, (1) Untuk mengetahui konsistensi terhadap standar pengelolaan MGMP Fisika di SMA Negeri dan Swasta Kabupaten Indragiri Hilir, (2) Untuk mengetahui pemanfaatan sumberdaya dalam MGMP Fisika di SMA Negeri dan Swasta Kabupaten Indragiri Hilir, (3) Untuk mengetahui aktifitas dan komunikasi dalam MGMP Fisika di SMA Negeri dan Swasta Kabupaten Indragiri Hilir,(4) Untuk mengetahui pola pelaksana MGMP Fisika di SMA Negeri dan Swasta Kabupaten Indragiri Hilir, (4) Untuk mengetahui dukungan Pemerintah dan Kepala Sekolah terhadap MGMP Fisika di SMA Negeri dan Swasta Kabupaten Indragiri Hilir,(5) Untuk mengetahui respon implementor MGMP Fisika di SMA Negeri dan SMA Swasta Kabupaten Indragiri Hilir. Responden penelitian adalah pengurus dan beberapa anggota MGMP Fisika SMA di Kabupaten Indragiri Hilir. Hasil yang diperoleh dari penelitian ini adalah (1) Konsistensi terhadap standar MGMP Fisika di SMA Negeri dan Swasta Kabupaten Indragiri Hilir Komunitas MGMP Fisika di SMA Negeri dan SMA Swasta Kabupaten Indragiri Hilir sudah baik karena sudah konsisten terhadap juknis dan standar operasioanal MGMP. Namum ada standar operasional yang belum dipedomani dengan baik,(2) Pemanfaatan sumberdaya dalam MGMP Fisika di SMA Negeri dan Swasta Kabupaten Indragiri Hilir Komunitas MGMP Fisika SMA di Kabupaten Indragiri Hilir sudah baik dengan memanfaatkan sarana dan prasarana yang ada di SMAN 1 Tembilahan dan SMAN 1 Tembilahan Hulu, (3) Aktifitas dan Komunikasi dalam MGMP Fisika di SMA Negeri dan Swasta tingkat Kabupaten Indragiri Hilir sudah terlaksana dengan baik yakni dalam penyampaian informasi baik pesan, ide, gagasan dilakukan secara verbal maupun dengan berbasis alat komunikasi, (4) Pola pelaksanaan kegiatan MGMP Fisika di SMA Negeri dan Swasta Kabupaten Indragiri Hilir sudah baik dengan pola pelaksanaan dilaksanakan secara rutin setiap bulan. , (5) Dukungan Pemerintah dan Sekolah terhadap MGMP Fisika SMA Negeri dan Swasta Kabupaten Indragiri Hilir sudah baik karena dalam pelaksanaan MGMP Fisika selalu mendapat dukungan dari Sekolah berupa bantuan dana kegiatan MGMP Fisika yang bersumber dari dana bantuan operasional sekolah, (6) Respon implementor terhadap program PKB melalui MGMP Fisika di SMA Negeri dan Swasta Kabupaten Indragiri Hilir belum memasukan materi pembuatan artikel ilmiah, buku teks, modul pembelajaran dan karya inovatif.
\end{abstract}

Kata Kunci: Program Keprofesian Berkelanjutan; Musyawarah Guru Mata Pelajaran Fisika

\section{PENDAHULUAN}

Sebuah organisasi termasuk organisasi pendidikan di sekolah mampu menghadapi perubahan dan ketidakpastian yang menjadi ciri kehidupan organisasi modern, maka perlunya mengembangkan sekolah sebagai sebuah organisasi pembelajar. Karakter utama organisasi pembelajar adalah senantiasa mencermati perubahan internal dan eksternal yang diikuti dengan upaya penyesuaian diri dalam rangka mempertahankan eksistensinya.

Program Pengembangan Keprofesian Berkelanjutan (PKB) ini diarahkan untuk dapat memperkecil jarak antara pengetahuan, keterampilan, kompetensi sosial dan kepribadian yang mereka miliki sekarang dengan apa 
yang menjadi tuntutan ke depan berkaitan dengan profesinya. Kegiatan PKB meliputi pengembangan diri, publikasi ilmiah, dan karya inovatif. PKB dapat dilaksanakan melalui kegiatan kolektif guru melalui lokakarya, Musyawarah Guru Mata Pelajaran (MGMP), kegiatan pembelajaran berbasis TIK, penilaian, pengembangan media pembelajaran, dan/atau kegiatan lainnya untuk kegiatan pengembangan keprofesionalan guru. Kegiatan publikasi ilmiah dilakukan dengan mengikuti presentasi pada forum ilmiah, publikasi ilmiah hasil penelitian ilmiah, membuat makalah tinjauan ilmiah, pulisan populer ilmiah, artikel ilmiah dalam bidang pendidikan, publikasi buku teks pelajaran, membuat modul pembelajaran, menulis buku dalam bidang pendidikan, dan karya terjemahan. Untuk kegiatan karya inovatif dapat dilakukan dengan menemukan teknologi tepat guna, menciptakan karya seni, memodifikasi alat pelajaran, dan mengikuti pengembangan penyusunan standar, pedoman, soal, dan sejenisnya. Kegiatan tersebut bertujuan untuk meningkatkan kompetensi dan profesional guru.

Potret rendahnya kualitas guru terlihat dari hasil Uji Kompetensi Guru (UKG) ditahun 2015, yang menunjukkan bahwa dari 1,6 juta guru yang mengikuti UKG, hanya 192 guru yang memperoleh nilai diatas 90,00. Sementara nilai rata-rata guru 53,05. Nilai rata-rata yang dicapai peserta UKG masih dibawah standar kompetensi minimal yang ditatapkan kemendikbud, yakni 55,00 (dari rentan nilai 10,00 s.d 100,00).

Tabel 1.1 Perkembangan nilai UKG 2012 - 2015

\begin{tabular}{|c|c|c|c|c|}
\hline \multirow{2}{*}{ Uraian } & \multicolumn{4}{|c|}{ Tahun Pelaksanaan } \\
\cline { 2 - 5 } & $\mathbf{2 0 1 2}$ & $\mathbf{2 0 1 3}$ & $\mathbf{2 0 1 4}$ & $\mathbf{2 0 1 5}$ \\
\hline Rerata nilai UKG guru & 45,85 & 47,84 & 48,95 & 56,77 \\
\hline
\end{tabular}

Sumber: Kementerian Pendidikan dan kebudayaan 2015

Walaupun secara fakta penulis tidak menemukan data tentang hasil UKG untuk Provinsi Riau khususnya Kabuapaten Indragiri Hilir, namun dari data secara nasional mewakili daerah Provinsi Riau. Peningkatan kompetensi guru merupakan suatu kewajiban yang harus dilaksanakan dalam meaksanakan tugas keprofesionalannya, seperti yang tertulis dalam Undang-Undang Nomor 14 Tahun 2005 tentang guru dan dosen pasal 20 yaitu, meningkatkan dan mengembangkan kualifikasi akademik dan kompetensi secara berkelanjutan sejalan dengan perkembangan ilmu pengetahuan, teknologi, dan seni.

Dari data di atas diperoleh bahwa PTK yang berstatus PNS akan berhak naik pangkat apabila pemenuhan syarat PKB sudah dipenuhi. Hal ini ada hubungannya dengan kegiatan PKB yang berupa pengembangan diri, karya ilmiah dan/atau karya inovatif. Berikut tabel angka kredit dari unsur PKB yang harus dipenuhi untuk kenaikan pangkat PNS Guru. 
Tabel 1.3 Angka Kredit yang harus dipenuhi dari Unsur PKB

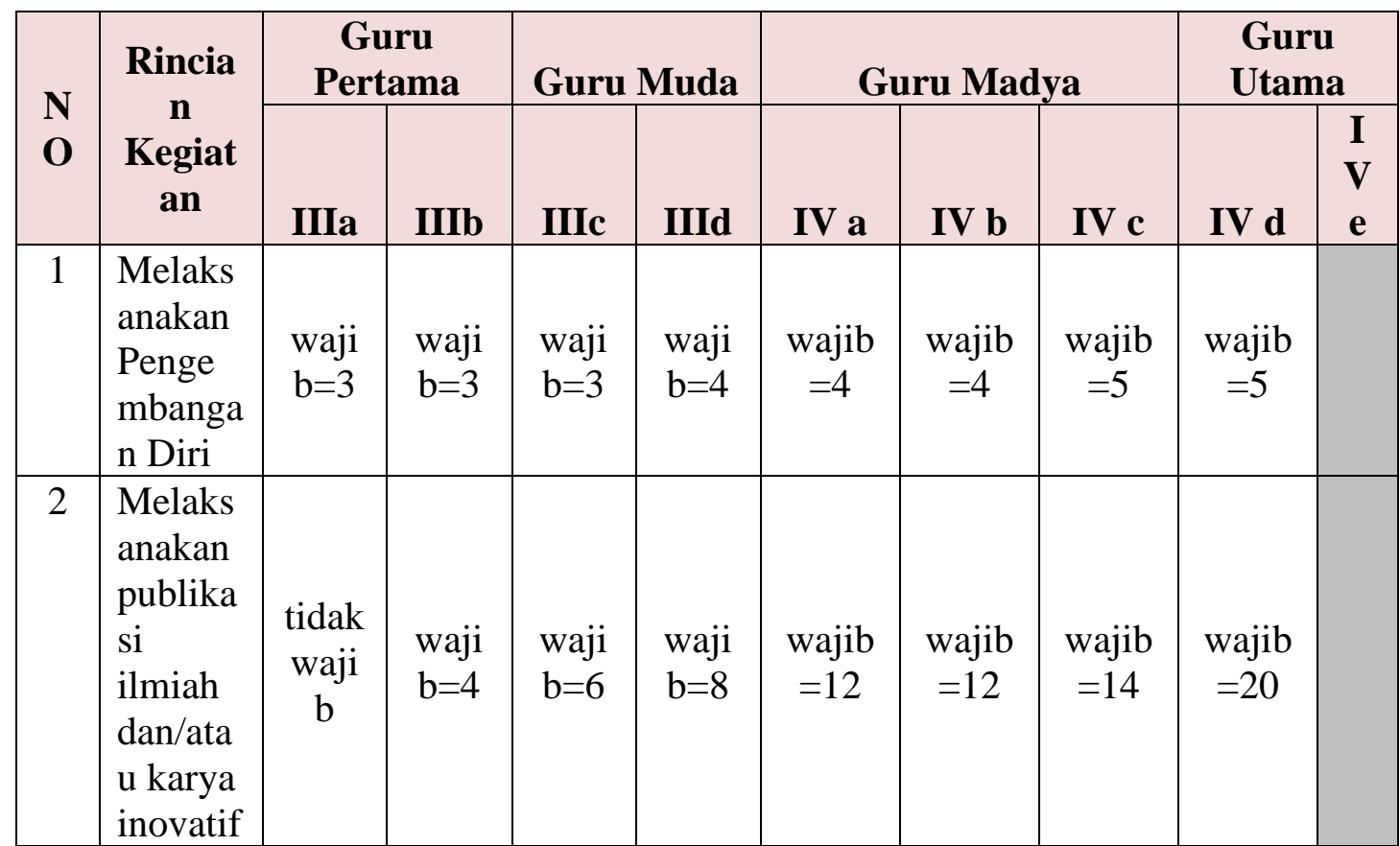

Sumber: Permendiknas Nomor 35 Tahun 2010

Dampak kenaikan pangkat guru disebabkan kompetensi dalam bidang pengembangan diri, membuat karya tulis ilmiah dan karya inovasi, ternyata terlihat jelas pada kenaikan pangkat dari IV/a ke IV/b karena pada tahapan ini harus membuat karya tulis ilmiah dan/atau karya inovasi alat peraga pembelajaran. Karya tulis ilmiah ini seolah menjadi momok bagi para guru yang akan naik pangkat sehingga karir guru banyak terhenti di golongan IV/a karena faktor malas, enggan atau bahkan ketidakmampuan membuat Karya Tulis Ilmiah. Kegiatan PKB yang berdampak pada kemampuan karya tulis ilmiah dan/atau karya inovatif adalah kegiatan kolektif guru yakni MGMP.

Kegiatan MGMP Fisika SMA diikuti oleh guru fisika yang bertugas pada SMA di Kabuapten Indragiri Hilir. Jumlah anggota MGMP Fisika SMA Kabupaten Indragiri Hilir berjumlah 60 guru. Kegiatan MGMP Fisika SMA di Kabuapten Indragiri Hilir telah dilaksanakan secara aktif mulai 2014, sebelum itu kegiatan yang dilaksanakan kurang aktif.

Berdasarkan permasalahan di atas, penulis melakukan penelitian tentang Implementasi Program Pengembangan Keprofesian Berkelanjutan melalui MGMP Fisika di SMA Negeri dan SMA Swasta Kabupaten Indragiri Hilir.

\section{METODOLOGI PENELITIAN}

Penelitian ini adalah penelitian lapangan yang artinya sebagai penelitian yang datanya diperoleh dengan cara mengumpulkan data dilapangan dengan pendekatan kualitatif. Pendekatan kualitatif dilaksanakan sebagai upaya memahami situasi tertentu dengan bentuk penelitian studi kasus (case study), yaitu suatu penelitian yang dilakukan secara intensif, terinci dan mendalam terhadap suatu organisasi, lembaga atau gejala tertentu.

Jenis penelitian kualitatif adalah sebuah tipe penelitian dimana peneliti mengandalkan pandangan dari 
partisipan, mengajukan pertanyaan yang bersifat umum dan luas, mengumpulkan data data yang sebagian besar terdiri dari kata kata atau teks dari para partisipan. Mendeskripsikan dan menganalisa katakata ini kedalam tema, dan melaksanakan penelitian ini tidak bisa bebas dari subjekvitas. Selain itu penelitian ini menekankan pada proses dari pada hasil.

\section{HASIL PENELITIAN DAN PEMBAHASAN}

1. Konsistensi terhadap standar kerja MGMP Fisika di SMA Negeri dan SMA Swasta Kabupaten Indragiri Hilir

Standar operasional penjamin mutu meliputi pembentukan tim penjamin mutu internal yang bekerja untuk mengaudit hasil temuan dan daftar usulan perbaikan yang ditujukan kepada pengurus MGMP Fisika. Dari hasil wawancara didapatkan informasi bahwa MGMP Fisika SMA di Kabupaten Indragiri Hilir memiliki tim penjamin mutu internal yang diangkat dari anggota MGMP Fisika SMA. Dalam hal ketaatan terhadap standar operasional MGMP di trianggulasikan dengan dokumen Anggaran Dasar dan Rumah Tangga MGMP Fisika SMA, dokumen program kerja, dokumen Pemdoman PKB. Dalam dokumen PKB dijelaskan bahwa pengelolaan MGMP harus berpedoman atau menggunakan panduan yang sudah disiapkan oleh Pemerintah.

2. Pemanfaatan sumberdaya dalam MGMP Fisika di SMA Negeri dan SMA Swasta Kabupaten Indragiri Hilir

Pengurus meminjam salah satu ruangan untu kegiatan MGMP Fisika di SMAN 1 Tembilahan Hulu dan SMAN 1 Tembilahan. Anggota dalam melaksnaakan kegiatan mendapatkan bantuan dana dari masing-masing sekolah yang besarnya bervariatif sesuai dengan kondisi keuangan sekolah.

3. Aktifitas dan komunikasi MGMP Fisika di SMA Negeri dan SMA

Swasta Kabupaten Indragiri Hilir.

Sebelum kegiatan MGMP Fisika dilaksanakan pengurus membuat surat pemberitahuan kepada seluruh anggota. Selain pengurus memberitahukan kepada anggota, pengurus mengkonsisikan tempat kegiatan dengan menghubungi sekolah yang dapat dijadikan tempat pertemuan. Dalam kegiatan MGMP Fisika dilakukan diskusi setelah penyampaian materi. Kehadiran anggota MGMP Fisika SMA belum semua aktif mengikuti kegiatan MGMP dikarenakan kondisi geografis yang hampir setengahnya daerah perairan. Pada akhir kegiatan pengurus menyampikan laporan kegiatan khususnya terkait dengan pendanaan kegiatan yang barusaja dilakukan.

4. Pola pelaksana MGMP Fisika di SMA Negeri dan SMA Swasta Kabupaten Indragiri Hilir

Kegiatan MGMP Fisika SMA rutin dilakukan setiap bulan dan minimal dalam satu tahun dilakukan sepuluh kali. Waktu pelaksnaan dilaksnakan pada hari sabtu pada setiap bulannya. Kegiatan MGMP Fisika SMA dilaksanakan secara mandiri. Narasumber kegiatan MGMP Fisika SMA dari anggota MGMP sendiri yang telah ditunjuk oleh pengurus.

5. Dukungan Pemerintah dan Sekolah terhadap MGMP Fisika di SMA Negeri dan SMA Swasta Kabupaten Indragiri Hilir

Dukungan pemerintah dapat diketahui melalui Petunjuk Teknis penggunaan dana Bantuan Operasioanal Sekolah, dimana dalam Juknis ini pemerintah telah membuat kebijakan bahwa dana BOS dapat digunakan 
untuk peningkatan mutu Pendidik dan tenaga Kependidikan. Salah satu jenis kegiatannya adalah melalui Musyawarah Guru Mata Pelajaran. Dalam hal ini Sekolah memberikan dukungan kepada Guru untuk mengikuti kegiatan komunitas MGMP sesuai dengan Mata Pelajaran yang diampu oleh guru tersebut.

6. Respon implementor terhadap kebijakan PKB melalui MGMP Fisika di SMA Negeri dan SMA Swasta Kabupaten Indragiri Hilir

Sebagian besar anggota aktif dalam kehadiran kegiatan MGMP Fisika. Kerjasama dalam kegiatan terjalin dengan baik antara pengurus, anggota, narasumber dan pengawas serta kepala sekolah. Pengurus memfasilitasi bagi anggota yang ingin melaksanakan seminar penelitian hasil penelitian tindakan kelas. Pengurus juga memfasilitasi anggota yang baru pulang dari pendidikan dan pelatihan untuk membagikan ilmu yang didapat melalui keguaiatan MGMP Fisika. Dalam kegiatan MGMP Fisika SMA seKabupaten Indragiri Hilir yang belum dilaksnakan terkait dengan PKB adalah membuat artikel ilmiah, buku teks, modul pembelajaran. Karya inovatif juga belum dilaksanakan. Namum untuk pembuatan soal ujian sekolah sudah dilaksanakan oleh komunitas MGMP Fisika SMA.

1. Konsistensi terhadap standar kerja MGMP Fisika di SMA Negeri dan SMA Swasta Kabupaten Indragiri Hilir

Menurut Deddy Mulyadi (2016: 72) menyatakan bahwa standar kebijakan harus jelas, sehingga tidak menimbulkan interpretasi yang menyebabkan terjadinya konflik diantara pelaksana kebijakan. Dinas pendidikan telah menetapkan standar pengembangan dan standar operasional
MGMP. Hal tersebut sebagai landasan dalam menjalankan MGMP yang bertujuan untuk memudahkan dalam pelaksanaan MGMP. Standar pengembangan MGMP adalah unsurunsur yang harus dimiliki oleh MGMP yang mencakup organisasi, program, pengelolaan sarana dan prasarana, sumber daya manusia, pembiayaan, dan penjaminan mutu.

Pada penelitian Manajemen MGMP Fisika di SMA Negeri dan SMA Swasta Kabupaten Indragiri Hilir juga sudah dilaksanakan sesuai dengan ketentuan yang ada, MGMP sebelum dilakukan pembentukan pengurus maka dilakukan musyawarah seluruh anggota. Dalam penyusunan program kerja melibatkan seluruh anggota untuk membahas program kerja yang akan dilaksanakan selama satu tahun. Standar operasional sumber daya manusia penentuan narasumber dan instruktur/guru inti, pendamping yang bersifat tetap, penentuan narasumber dan guru inti dilakukan dengan pertimbangan penguasaan kompetensi yang akan disampaikan sesuai dengan program kerja MGMP Fisika. Standar operasional sarana dan prasarana meliputi langkah-langkah pengelolaan sarana dan prasarana yang dilakukan dalam kegiatan MGMP Fisika. Gedung ataupun sarana tempat MGMP Fisika meminjam gedung SMAN 1 Tembilahan dan SMAN 1 Tembilahan sebagai tempat aktifitas kegiatan MGMP Fisika SMA karena letak sekolah ini yang sangat setrategis dan berada dipusat Kabupaten Indragiri Hilir. Standar operasioanal pengelolaan yang terdiri dari penyusunan program kegiatan, pelaksanaan program kegiatan, monitoring dan evaluasi kegiatan. MGMP Fisika SMA di Kabupaten Indragiri Hilir belum memiliki tim penjamin mutu internal yang diangkat dari anggota MGMP 
Fisika SMA. Lingkup Manajemen MGMP meliputi: 1) Organisasi, yaitu struktur kepengurusan, landasan dan acuan kerja,serta kerangka teknis organisasi, b). Program, yaitu hal-hal yang berkaitan dengan perencanaan, pelaksanaan dan evaluasi kegiatan, tujuan dan sasaran yang akan dicapai,c). Pengelolaan, yaitu hal-hal yang berkaitan dengan proses pelaksanaan organisasi yang bersifat teknis, pelaksanaan acuan kerja dan sebagainya, d). Sarana dan prasarana, adalah fasilitas fisik untuk menunjang MGMP e). Pembiayaan, yaitu dana yang digunakan untuk kegiatan MGMP, mulai dari perencanaan, sirkulasi, pelaporan dan evaluasi, f). Penjaminan Mutu adalah sistem untuk mengaudit kesesuaian antara pelaksanaan MGMP dengan standar yang ditetapkan. Organisasi dapat dikatakan efektif apabila memiliki dan memenuhi standar atau acuan sebagai landasan dalam melaksanakan program untuk mencapai visi, misi dan tujuan.

2. Pemanfaatan sumberdaya dalam MGMP Fisika di SMA Negeri dan SMA Swasta Kabupaten Indragiri Hilir

Menurut Mulyasa (2017:152) kegiatan MGMP dilaksankaan di sanggar yaitu suatu tempat atau pusat kegiatan guru dari berbagai sekolah yang letaknya strategis dan mudah untuk berkumpul. Maka dalam hal ini MGMP Fisika SMA dilaksanakan di SMAN 1 Tembilahan dan SMAN 1 Tembilahan Hulu yang secara geografis sangat startegis. Seorang guru hendaknya meningkatkan kompetensi diri dengan cara melalui memperbanyak mengikuti pendidikan dan pelatihan, workshop, yang memperkaya referensi bacaan dan lain sebagainya dengan menyisihkan beberapa persen dari tujangan profesi yang diperolehnya.
MGMP Fisika di SMAN 1 Tembilahan Hulu Pemanfaatan sumberdaya MGMP baik sumberdaya manusia maupun sumber daya non manusia meliputi pembiayaan dan sarana prasarana. Didalam melaksanakan MGMP pengurus meminjam salah satu ruangan untuk kegiatan MGMP Fisika di SMAN 1 Tembilahan Hulu dan SMAN 1 Tembilahan. Keadaan ruang pertemuan yang nyaman dan asri membuat peserta antusias dalam mengikuti kegiatan MGMP Fisika SMA. Didalam pemanfaaatan sumber keuangan bendahara mengelola keuangan sesuai dengan keadaan keuangan yang diperoleh dari anggota dan sekolah. Pembiayaan pendidikan yang memadai mempunyai peran yang sangat penting dalam hal meningkatkan mutu pendidikan khususnya melalui komunitas MGMP Fisika SMA.

3. Aktifitas dan komunikasi MGMP Fisika di SMA Negeri dan SMA Swasta Kabupaten Indragiri Hilir.

Menurut Deddy Mulyadi (2016: 72) menyatakan bahwa dalam implementasi sebuah program perlu didukung dan dikomunikasikan terhadap semua anggota maupun dengan organisasi lainnya. Sebelum kegiatan MGMP Fisika dilaksanakan pengurus membuat surat pemberitahuan kepada seluruh anggota. Selain pengurus memberitahukan kepada anggota, pengurus mengkondisikan tempat kegiatan dengan menghubungi sekolah yang dapat dijadikan tempat pertemuan. Dalam kegiatan MGMP Fisika dilakukan diskusi setelah penyampaian materi. Kehadiran anggota MGMP Fisika SMA belum semua aktif mengikuti kegiatan MGMP dikarenakan kondisi geografis yang hampir setengahnya daerah perairan. Pada akhir kegiatan pengurus menyampikan laporan kegiatan khususnya terkait 
dengan pendanaan kegiatan yang baru saja dilakukan.

Kiprah MGMP khususnya MGMP tingkat SMA secara umum belum berjalan secara optimal sebagaimana yang diharapkan. Bahkan dibeberapa tempat khususnya pada tingkat Kabupaten/Kota dan Provinsi hai ini belum berjalan dengan baik. Di MGMP Fisika di SMA Kabupaten Indragiri Hilir ditemukan masalah yang berkaitan dengan kehadiran anggota dalam kegiatan MGMP salah satu kendala yang dihadapi adalah alat transportasi yang susah didapat karena kondisi geografis dan kurang dukungan dari penentu kebijakan baik pada tingkat sekolah (Kepala Sekolah), Kabupaten/Kota (Dinas), Propinsi bahkan sampai tingkat pusat. Oleh karena itu dalam rangka mengoptimalkan kembali peranan MGMP tingkat SMA sebagai wadah kordinasi antara guru mata pelajaran di sekolah, program yang menunjang pengurus MGMP tingkat SMA menjadi sangat penting.

4. Pola pelaksana MGMP Fisika di SMA Negeri dan SMA Swasta Kabupaten Indragiri Hilir

Menurut Sholichin Abdul Wahab (2012:165) menyatakan bahwa salah satu faktor keberhasilan implementasi kebijakan karakteristik dari instansi pelaksana dan melaksanakan 12 kegiatan yang dituangkan dalam 12 kali pertemuan dalam satu tahun. Dalam hal ini instansi pelaksana adalah komunitas MGMP Fisika di KabupatenIndragiri Hilir. Kegiatan MGMP Fisika SMA rutin dilakukan setiap bulan dalam satu tahun dilakukan sepuluh kali. Waktu pelaksanaan dilaksanakan pada hari sabtu pada setiap bulannya. Kegiatan MGMP Fisika SMA dilaksanakan secara mandiri. Narasumber kegiatan MGMP Fisika SMA dari anggota
MGMP sendiri yang telah ditunjuk oleh pengurus. Dalam hal ini sudah berjalan dengan baik namun saja pada pertemuan terdapat guru yang berhalangan hadir dikarenakan akses yang jauh sehingga guru mengalami kesulitan untuk menghadiri kegiatan MGMP tersebut. MGMP Fisika SMA Negeri dan SMA swasta hanya melakukan 10 kali pertemaun dalam setahun yang seharusnya pertemuan ini dilakkan 12 kali pertemuan dalamsetip tahunnya hal ini dikarenakan masih banyak keterbatasan didalam kegiatan MGMP ini seperti sulitnya mengalokasikan dana dan akses beberapa sekolah yang sulit untuk datang pada kegiatan yang dilaksanakan, disamping itu pembinaan serta perhatian dari stakeholder pendidikan masih belum optimal.

5. Dukungan Pemerintah dan Sekolah terhadap MGMP Fisika di SMA Negeri dan SMA Swasta Kabupaten Indragiri Hilir

Solahudin Kusumanegara (2015:113) menyatakan bahwa dukungan sosoal, politik dan ekonomi terlebih pada dukungan kelompok kepentingan mempengaruhi imlementasi kebijakan. Dalam hal ini dukungan dari Pemerintah, Dinas Pendidikan, dan dari sekolah khususnya sangat diperlukan dalam pelaksanaan kegiatan MGMP Fisika di Kabupaten Indragiri Hilir. Kepala Sekolah dari SMAN 1 Tembilahan Hulu dan SMAN 1 Tembilahan memberikan sarana dan prasaran berupa tempat pelaksanaan MGMP Fisika dilaksanakan. Dukungan keuangan oleh Kepala Sekolah dari masing-masing sekolah diperuntukkan untuk kegiatan transportasi dan konsumsi pada saat kegiatan MGMP Fisika SMA dilaksanakan.

Seharusnya pemerintah harus maksimal dalam mendukung pelaksanan MGMP ini karena kegiatan 
ini dapat meningkatkan kinerja guru. Karena selama MGMP Fisika SMA dari tahun 2015 sampai dengan tahun 2020 komunitas ini belum mendapatkan bantuan dari pemerintah secara langsung. Bantuan dari pemerintah selama ini melalui penggunaan dana Bantuan Operasional Sekolah pada sub anggran peningkatan mutu dan kompetensi pendidik dan tenaga kependidikan yang masing-masing sekolah menganggarkan sesuai dengan kemampuan keuangan dana sekolah. Salah satu contoh bentuk dukungan dari pemerintah yang bisa dilaksanakan berupa pelaksanaan pelatihan dan workshop dengan mendatangkan nara sumber yang menarik dan juga. Namun untungnya dukungan keuangan oleh Kepala Sekolah dari masing-masing sekolah sangat membantu dan diperuntukkan untuk kegiatan transportasi dan konsumsi pada saat kegiatan MGMP Fisika SMA dilaksanakan. Hal ini sangat membantu para guru didalam meningkatkan kinerja nya dan memotivasi guru untuk melaksanakan kegiatan MGMP setiap bulannya.

6. Respon implementor terhadap kebijakan PKB melalui MGMP Fisika di SMA Negeri dan SMA Swasta Kabupaten Indragiri Hilir

Menurut Deddy Mulyadi (2016:68) menyatakan bahwa bentuk respon para implementor kebijakan dapat berupa komitmen, kejujuran, dan sifat demokratis. Pengurus MGMP Fisika sangat aktif dalam melaksanakan kegiatan MGMP. Kerjasama dalam kegiatan terjalin dengan baik antara pengurus, anggota, narasumber dan pengawas serta kepala sekolah. Pengurus memfasilitasi bagi anggota yang ingin melaksanakan seminar penelitian hasil penelitian tindakan kelas. Pengurus juga memfasilitasi anggota yang baru pulang dari pendidikan dan pelatihan untuk membagikan ilmu yang didapat melalui keguaiatan MGMP Fisika.

Dalam kegiatan MGMP Fisika SMA se-Kabupaten Indragiri Hilir yang belum dapat dilaksanakan terkait dengan PKB adalah membuat artikel ilmiah, buku teks, modul pembelajaran. Karya inovatif juga belum dilaksanakan. Namun untuk pembuatan soal ujian sekolah sudah dilaksanakan oleh komunitas MGMP Fisika SMA. Hal ini sangat disayangkan sekali karena seharusnya didalam kegiatan MGMP tersebut masing-masing guru sudah mampu membuat modul dan karya ilmiah untuk menunjang kinerja nya.

\section{SIMPULAN}

Hasil penelitian ini dilakukan secara kualitatif. Berdasarkan data yang diperoleh dari wawancara, observasi dan dokumentasi tentang Implementasi Program Pengembangan Keprofesian Berkelanjutan melalui MGMP Fisika di SMA Negeri dan SMA Swasta Kabupaten Indragiri Hilir.

1. Konsistensi terhadap standar MGMP Fisika di SMA Negeri dan Swasta Kabupaten Indragiri Hilir Komunitas MGMP Fisika di SMA Negeri dan SMA Swasta Kabupaten Indragiri Hilir sudah baik karena sudah konsisten terhadap juknis dan standar operasioanal MGMP. Namum ada standar operasional yang belum dipedomani dengan baik.

2. Pemanfaatan sumberdaya dalam MGMP Fisika di SMA Negeri dan Swasta Kabupaten Indragiri Hilir Komunitas MGMP Fisika 
SMA di Kabupaten Indragiri Hilir sudah baik dengan memanfaatkan sarana dan prasarana yang ada di SMAN 1 Tembilahan dan SMAN 1 Tembilahan Hulu

3. Aktifitas dan Komunikasi dalam MGMP Fisika di SMA Negeri dan Swasta tingkat Kabupaten Indragiri Hilir sudah terlaksana dengan baik yakni dalam penyampaian informasi baik pesan, ide, gagasan dilakukan secara verbal maupun dengan berbasis alat komunikasi.

4. Pola pelaksanaan kegiatan MGMP Fisika di SMA Negeri dan Swasta Kabupaten Indragiri Hilir sudah baik dengan pola pelaksanaan dilaksanakan secara rutin setiap bulan.

5. Dukungan Pemerintah dan Sekolah terhadap MGMP Fisika SMA Negeri dan Swasta Kabupaten Indragiri Hilir sudah baik karena dalam pelaksanaan MGMP Fisika selalu mendapat dukungan dari Sekolah berupa bantuan dana kegiatan MGMP Fisika yang bersumber dari dana bantuan operasional sekolah. Adapun dukungan dari pemerintah merupakan bantuan tidak langsung, yakni dengan kebijakan bahwa dana Bantuan Operasional Sekolah dapat digunakan untuk kegiatan MGMP.

6. Respon implementor terhadap program PKB melalui MGMP Fisika di SMA Negeri dan Swasta Kabupaten Indragiri Hilir

belum memasukan materi
pembuatan artikel ilmiah,
buku teks,
pembelajaran dan karya
inovatif.

\section{DAFTAR PUSTAKA}

Arwildayanto, Suking. A dan Sumar. W.T. (2018). Analisis Kebijakan Pendidikan: Kajian Teoritis, Eksploratif, dan Aplikatif. Bandung: Cendikia Press

Asneta Aneta. (2010). Implementasi

Kebijakan Program

Penanggulangan Kemiskinan

Perkotaan (P2KP) di Kota

Gorontalo. Jurnal Administrasi

Publik, Volume 1 No. 1 Thn.

2010.

Barella, Y. (2014). The Roles of English Teacher working Group to suppurt teacher profesional development. Surakarta: UNS

Deddy Mulyadi. (2016). Studi Kebijakan Publik dan Pelayanan Publik. Bandung: Alfabeta

Eko Putro Widoyoko. (2018). Teknik Penyusunan Instrumen Penelitian. Yogyakarta: Pustaka Pelajar.

Eko Siproyanto. (2015). Analisis Pengembangan Profesionalisme Guru Berkelanjutan di SMKN 2 Sragen.

core.ac.uk.download/pdf/1486096 71/pdf

Hasbullah, M. (2015). Kebijakan Pendidikan: Dalam Perspektif Teori, Aplikasi, dan Kondisi Objektif. Jakarta: Rajawali Pers. 
Helmi, YF. (2018). The strategy in improving english teachers' profesionalism trough MGMP. Journal Teachers in the Digital Age, III, 345.

Ika Devi Pramudiana. (2017). Implementasi Kebijakan Pendidikan Inklusif untuk Anak Berkebutuha Khusus di Surabaya. Jurnal Dimensi Pendidikan dan Pembelajaran, Vol. 5 No.1 $\underline{\text { Januari } 2017}$

Kemendiknas. (2010). Pedoman Pengelolaan Pengembangan keprofesian berkelanjutan. Jakarta: Direktur Jendral PMPTK.

Komara. E dan Anang Mauludin. (2016). Pengembangan Keprofesian Berkelanjutan. Bandung: Refika Aditama

Mulyasa. (2017). Uji Kompetensi Guru dan Penilaian Kinerja Guru. Bandung: PT Remaja Rosdakarya

Nanang Priatna dan Titi Sukamto. (2013). Pengembangan Profesi Guru. Bandung: PT Remaja Rosdakarya Offset.

Nurkolis. (2017). Efektifitas Pengembangan Keprofesian Berkelanjutan. http://ejournal.uksw.edu/kelola/art icle/view/971

Peraturan Menteri Negara Pemberdayaan Aparatur Negara dan reformasi Birikrasi Nomor 16 Tahun 2009 Jabatan Fungsional Guru dan Angka Kreditnya. Jakarta.

Peraturan Pemerintah Nomor 19 Tahun 2005 Standar Nasional Pendidikan. Jakarta.
Purwoko, A. (2017). Efforts in improving teacher's competencies through collaboration between teacher forum on subject matter and pre-service teacher training institution. JPII from http://journal.unnes.ac.id

Rusdiana. (2015). Kebijakan Pendidikan: Dari Filosofi ke Implementasi. Bandung: $\mathrm{CV}$. Pustaka Setia.

Rosihan Anwar. (2015). Pengaruh MGMP Terhadap Profesionalisme dan Kinerja Mengajar Guru. http.ejournal.upi.edu

Saud Syaefudin. (2017). Pengembangan Profesi Guru. Bandung: Alfabeta

Solichin Abdul Wahab. (2011). Analisis Kebijakan Publik. Malang: UMM Press.

\section{(2017). Analis}

dan Model-model Implementasi Kebijakan Publik. Jakarta: Bumi Aksara.

Subarsono. (2005). Analisis Kebijakan Publik. Yogyakarta: Pustaka Pelajar.

Sudrajat. (2017). Mengelola pengembangan keprofesian berkelanjutan. Bandung : Pustaka Setia

Surya, M. (2014). Psikologi Pembelajaran dan Pengajaran. Bandung: Pustaka Bani Quraisy

Suyanto dan Asep Jihad. (2013). Menjadi Guru Profesional. Jakarta: Erlangga 
Su'ud, U.S. (2017). Pengembangan Profesi Guru. Bandung: Alfabeta

Tachjan. (2006). Implementasi Kebijakan Publik. Bandung: AIPI

Wiratna Sujarweni. (2014). Metodologi Penelitian. Yogyakarta: Pustaka Baru Press.

Undang-undang Republik Indonesia Nomor 20 Tahun 2003 Sistem Pendidikan Nasional. Jakarta.

Undang-undang Republik Indonesia Nomor 14 Tahun 2005 Guru dan Dosen. Jakarta.

Vera Talimbung dan Samsul Hadi (2014). An Evaluation of Physick Teacer Association Programs of Senior High School at Sleman District. Jurnal Evaluasi Pendidikan Vol.2 No.02, 2014. 